\title{
Hubungan Self Efficacy dan Goal Orientation terhadap Career Development pada Para Pencari Kerja PT. Bina Talenta
}

\author{
Rochimah Imawati, Andri Hadiansyah, Aulia Fadjrina, Dian Marita, Iwan Hadi Gautama, \\ Mutiara Wulan Ramadhani
}

Program Studi Psikologi, Fakultas Psikologi dan Pendidikan
Universitas Al Azhar Indonesia, Jl. Sisingamangaraja, Jakarta 12110

Penulis untuk korespondensi/E-mail: rochimah@uai.ac.id

\begin{abstract}
Abstrak - Dunia industri dan organisasi sangat membutuhkan sumber daya manusia (SDM) yang memiliki aspek psikologis individual yang tangguh. Karenanya dibutuhkan pelatihan tertentu dalam mengenalkan dan merubah cara pandang para pencari kerja, agar lebih siap menerima tentangan pekerjaan baru, dan mampu mengemban tugas dalam dunia kerja. Adapun Dalam penelitian ini yang akan menjadi permasalahan adalah, apakah variabel self-efficacy dan goal orientation dapat mempengaruhi secara langsung terhadap career development pada para pencari kerja. Sebagai bagian dari penelitian ilmiah dalam bidang Psikologi Industri dan Organisasi, maka yang menjadi tujuan penelitian ini adalah sebagai berikut: Untuk mengetahui apakah ada pengaruh dari varaiabel exogen (self-efficacy dan goal orientation) terhadap variabel endogen (career development); Untuk menguji model teoritis tentang variabel endogen (career development) serta beberapa modifikasinya; Untuk mengetahui seberapa dominan variable-variabel exogen (independent) terhadap career development. Berdasarkan hasil analisis data penelitian dan pembahasannya disimpulkan bahwa: Ada hubungan yang positif dan signifikan antara self efficacy dan goal orientation dengan career development individu pencari kerja PT. Bina Talenta; Ada hubungan yang positif dan signifikan antara self efficacy dan career development individu pencari kerja di PT. Bina Talenta; Ada hubungan yang positif dan signifikan antara goal orientation dengan career development individu pencari kerja di PT. Bina Talenta.
\end{abstract}

Abstract - The industrialized world and organization is now in desperate need of human resources (HR), which has a strong individual psychological aspects. Would require specific training in introducing and change the way job seekers, to be more ready to accept the challenge of a new job, and able to carry out tasks in the workplace. As this study will be a problem is, if the self-efficacy and goal orientation variables may affect directly to the career development on job seekers. As part of the scientific research in the field of industrial and organizational psychology, it is the goal of this study are as follows: To determine whether there was an effect of exogenous variables (self-efficacy and goal orientation) on endogenous variables (career development); To test the theoretical model of endogenous variables (career development) as well as some modifications; To find out how dominant exogenous variables (independent) to career development. Based on the results of data analysis and discussion concluded that: There is a positive and significant relationship between self-efficacy and goal orientation with individual career development jobseekers PT. Bina Talenta; There is a positive and significant relationship between self-efficacy and career development of individual job seekers in PT. Bina Talenta; There is a positive and significant relationship between goal orientation with individual career development job seekers in PT. Bina Talenta.

Keyword - Self efficacy, Goal orientation, Career Development 


\section{PENDAHULUAN}

Pengangguran menurut SUPAS (Survei Penduduk Antar Sensus) 1985 didefinisikan sebagai mereka yang mencari pekerjaan atau berusaha mencari pekerjaan yang tidak terbatas dalam jangka waktu seminggu yang lalu saja, tetapi bisa dilakukan beberapa waktu sebelumnya asalkan dalam kurun waktu satu minggu sebelum pencacahan masih dalam status menunggu jawaban. Faktor mendasar yang menjadi penyebab masih tingginya tingkat pengangguran di Indonesia diantaranya adalah ketidaksesuaian antara hasil yang dicapai antara pendidikan dengan lapangan kerja; ketidakseimbangan permintaan dan penawaran tenaga kerja; dan kualitas Sumber Daya Manusia (SDM) yang dihasilkan masih rendah. Umumnya perusahaan atau penyedia lapangan kerja membutuhkan tenaga yang siap pakai, artinya sesuai dengan pendidikan dan ketrampilannya, namun dalam kenyataan tidak banyak tenaga kerja yang siap pakai tersebut.

Faktor-faktor individual seseorang juga pengaruhi dalam memperoleh lapangan kerja sebagai bagian dari karirnya. Faktor-faktor individual tersebut, selain masalah kompetensi dan tingkat pendidikan; adalah kesiapannya dalam memilih dan menerima pekerjaan yang tersedia, dimana seringkali diluar yang 'diharapkan'. Dalam era global yang sangat kompetitif, tentunya dunia industri dan organisasi sangat membutuhkan SDM yang memiiliki aspek psikologis individual yang tangguh. Aspek individual tersebut diantaranya adalah self-efficacy (keyakinan mampu melaksanakan tugas) dan goal orientation (tujuan pencapaian).

Penulisan ini akan menyampaikan hasil penelitian yang menjadi permasalahan yaitu: apakah variabel self-efficacy dan goal orientation dapat mempengaruhi secara langsung terhadap career development pada para pencari kerja.

\section{LANDASAN TEORI}

\section{Pengembangan Karir \\ Arti Karir}

Arti karir secara luas meliputi jenis pekerjaan yang ditekuni oleh seseorang baik yang mendatangkan keuntungan materi atau tidak, karir tidak hanya bekerjanya seseorang dalam suatu organisasi kerja atau instansi, jadi masuk dalam kategori ini adalah ibu rumahtangga, pekerja sosial, pemimpin perkumpulan non-profit dan sebagainya. Namun dalam pembahasan ini dibatasi pada karir dalam organisasi kerja [1].

Dari sekian banyak terjemahan karir, dipilahkan dalam 2 (dua) kategori yaitu: sisi semantik dan sisi konseptual. Secara semantik karir yang merupakan perjalanan hidup seseorang dalam bekerja mengandung banyak beban yang harus ditanggung sepanjang hidup selama bekerja, namun sekaligus menunjukkan tujuan atau arah hidup seseorang. Maka secara semantik karir diterjemahkan sebagai: "Perjalanan hidup seseorang selama bekerja yang mencerminkan tujuan hidup". Sedangkan secara konseptual dapat dijelaskan bahwa: "Karir merupakan persepsi individu mengenai urutan sikap dan perilaku yang berhubungan dengan pengalaman dan kegiatan yang berkaitan dengan pekerjaan sepanjang hidup seseorang". Dalam karir mencakup pula penjelasan tentang konsep diri yaitu dimana karir seseorang dapat merupakan perwujudan dari konsep diri yang berkaitan dengan ruang lingkup pekerjaan [2].

\section{Pengertian Pengembangan Karir}

Pengembangan karir adalah suatu proses yang disengaja dan melaluinya seseorang menjadi sadar akan atribut-atribut yang berhubungan dengan karir personal dan rangkaian langkah sepanjang hidup yang menyumbang pada pemenuhan karirnya [2]. Menurut Veithzal Rivai, pengembangan karir adalah proses peningkatan kemampuan kerja individu yang dicapai dalam rangka mencapai karir yang diinginkan [4]. Simamora menyatakan bahwa pengembangan karir meliputi perencanaan karir dan manajemen karir [5]. Memahami pengembangan karir dalam sebuah organisasi membutuhkan suatu pemeriksaan atas dua proses, yaitu bagaimana individu merencanakan tujuan karirnya dan bagaimana organisasi merancang program pengembangan karir atau manajemen karirnya.

\section{Tujuan Pengembangan Karir}

Tujuan pengembangan karier dalam organisasi adalah membantu pencapaian tujuan individu karyawan dan perusahaan; kesejahteraan karyawan; membantu karyawan menyadari kemampuannya; memperkuat hubungan antara karyawan dan perusahaan; membuktikan tanggung jawab sosial; membantu pelaksanaan programprogram perusahaan; mengurangi turn-over dan biaya kekaryawanan lainnya; mengurangi keusangan profesi dan manajerial; meningkatkan analisis dari keseluruhan karyawan; menggiatkan 
suatu pemikiran (pandangan) jarak waktu yang panjang [6].

\section{Self efficacy \\ Definisi Self efficacy}

Self efficacy adalah keyakinan dalam diri seseorang atas kemampuannya menghadapi situasi tertentu. Self efficacy mempengaruhi persepsi, motivasi dan tindakannya dalam berbagai cara, dan mampu mempengaruhi seberapa banyak upaya yang digunakan dan seberapa lama seseorang dapat bertahan dalam mengatasi kehidupan yang sulit. Ketika seseorang merasa yakin mamapu menyelesaikan permasalahannya, maka ia akan berusaha keras dan menjadi sungguh berhasil. Menurut Bandura dalam Wade \& Tavris, selfefficacy tdak dibawa dari lahir, tetapi melalui pengalaman dan proses pembelajaran pada lingkungannya, belajar dari kegagalan, mempelajari dan menguasai kemampuan baru. Self-efficacy juga diperoleh dari role-model yang mengajari bahwa ambisi kita pantas diraih, serta dari orang-orang yang memberikan umpan balik, memberikan dukungan terhadap kita. Bandura juga mengatakan bahwa self efficacy sangat berperan dalam kehidupan seseorang melebihi pengetahuan tentang diri (self knowledge) [7].

Self efficacy mempengaruhi motivasi seseorang untuk melakukan suatu tindakan. Self efficacy juga mempengaruhi motivasi dalam beberapa aspek seperti dalam menentukan tujuan yang seseorang tetapkan untuk dirinya, seberapa besar usaha yang mereka lakukan, berapa lama ia mampu bertahan menghadapi kesulitan dan ketahanan dalam kegagalan, ketika berhadapan dengan kehilangan dan kesulitan. Seseorang yang tidak memiliki keyakinan akan kemampuan yang ia miliki, usaha dan motivasi dalam menjalankan tugas dan pekerjaannya pun akan melemah dan mempengaruhinya dengan cepat. Mereka yang memiliki kepercayaan diri yang kuat pada kemampuan diri akan berusaha lebih keras dan lebih termotivasi bekerja ketika menghadapi kesulitan. Hal ini juga menyangkut self efficacy individu dalam pencapaian kariernya.

\section{Karakteristik Self efficacy}

Karakteristik self efficacy digambarkan oleh Bandura [8] pada tabel 1.

Tabel 1. Karakteristik self efficacy

\begin{tabular}{cll}
\hline No & \multicolumn{1}{c}{ Self efficacy Rendah } & \multicolumn{1}{c}{ Self efficacy Tinggi } \\
\hline A & $\begin{array}{l}\text { Menetapkan cita- cita atau tujuan yang } \\
\text { rendah }\end{array}$ & Menetapkan tujuan cita-cita yang tinggi \\
\hline B & Kurang komitmen & Lebih komitmen \\
\hline C & Mengerahkan sedikit usaha & Mengerahkan banyak usaha \\
\hline D & Menyerah pada sedikit tantangan & Lebih ulet \\
\hline E & Membayangkan skenario kegagalan & Membayangkan skenario keberhasilan \\
\hline F & Pesimis & Optimis \\
\hline G & Menghindari tugas sulit & Menerima tugas sulit \\
\hline H & Kurang berani mencoba hal baru & Bersedia mencoba hal baru \\
\hline I & Cenderung membatasi diri & Berusaha mengembangkan diri \\
\hline J & $\begin{array}{l}\text { Memandang kemampuan sebagai kapasitas } \\
\text { yang tidak dapat diubah }\end{array}$ & $\begin{array}{l}\text { Memandang kemampuan sebagai keahlian yang } \\
\text { dapat diandalkan }\end{array}$ \\
\hline K & $\begin{array}{l}\text { Mengatribusikan kegagalan karena kurang } \\
\text { kemampuan }\end{array}$ & $\begin{array}{l}\text { Mengatribusikan kegagalan karena kurangnya } \\
\text { usaha atau keterampilan }\end{array}$ \\
\hline L & Menekankan perbedaan dengan orang lain & Meningkatkan peningkatan diri dan penyelesaian \\
\hline M & Gentar dala menghadapi tugas sulit & Tidak mundur dalam menghadapi tugas sulit \\
\hline N & $\begin{array}{l}\text { Merasa tidak mampu mengatasi persoalan } \\
\text { sesukses orang lain }\end{array}$ & $\begin{array}{l}\text { Merasa mampu mengatasi persoalan lebih sukses } \\
\text { dari orang lain }\end{array}$ \\
\hline O & Bertahan dalam defisiensi & Bertahan dalam kegigihan \\
\hline P & Lebih mudah stress, cemas dan depresi & Tidak mudah mengalami gangguan emosional \\
\hline Q & Memiliki kerusakan pada respon sistem & Memiliki sisitem syaraf otonom yang lebih sehat \\
& syaraf otonom seperti rusaknya fungsi & \\
kegagalan & & \\
\hline & & \\
\hline
\end{tabular}




\section{Dimensi-dimensi Self efficacy dalam Kerja}

Dalam melakukan pengukuran terhadap tingkat self efficacy yang dimiliki individu dapat diukur melalui tiga dimensi self efficacy. Menurut Bandura, ketiga dimensi self efficacy yang digunankan adalah [8]:

1. Tingkat kesulitan tugas (Magnitude)

Yaitu derajat kesulitan tugas dimana individu dapat merasa mampu dalam melakukan suatu tugas mulai dari tugas yang sederhana, tugas yang agak sulit, sampai tugas yang sangat sulit.

2. Situasi umum (Generality). Yaitu rentang situasi dimana individu merasa yakin akan kemampuan dirinya. Individu dapat merasa yakin mengenai kemampuannya hanya dalam suatu aktivitas dan situasi tertentu atau dalam serangkaian aktivitas atau situasi yang bervariasi.

3. Kekuatan dalam melaksanakan tugas (Strength). Yaitu kuatnya keyakinan individu mengenai kemampuan menurut pikirannya. Individu yang memiliki keyakinan yang kurang kuat mengenai kemampuannya, dengan mudah untuk menyerah bila menghadapi hambatan dalam menghadapi suatu tugas. Sebaliknya, seseorang yang memiliki keyakinan yang kuat mengenai kemampuannya, akan terus berusaha meskipun mengalami hambatan dalam melakukan suatu tugas. Semakin kuat self efficacy seseorang, maka semakin besar kemungkinannya untuk memilih tugas yang menantang. Semakin lama individu dapat bertahan dalam tugas tesebut, maka semakin besar kemungkinannya untuk dapat berhasil melakukan tugas tersebut.

Ketiga dimensi itu berhubungan erat satu sama lainnya. Bandura mengatakan bahwa tinggi rendahnya self efficacy individu selalu diukur dalam hubungannya dengan ketiga dimensi tersebut [8]. Individu dikatakan memiliki self efficacy tinggi jika individu tersebut merasa mampu melakukan berbagai tugas, mulai dari tugas yang sederhana sampai tugas yang sangat sulit. Individu memiliki keyakinan yang kuat mengenai kemampuannya bukan hanya dalam suatu aktivitas suatu situasi tertentu, tetapi dalam serangkaian aktivitas atau situasi yang bervariasi.

\section{Goal orientation}

\section{Pengertian Goal orientation}

Tujuan atau goal adalah suatu hasil atau keadaan ideal yang diinginkan seorang individu dimana individu akan bekerja atau berusaha demi terwujudnya hasil tersebut, dan memiliki nilai tersendiri bagi orang tersebut. Goal sangat penting karena merupakan panduan dari tindakan yang akan dilakukan karena goal mengarahkan, menyalurkan dan menetapkan apa yang harus dilakukan. Goal juga memotivasi perilaku karena goal adalah bentuk dari motivator dan penyemangat. Tanpa adanya goal maka tidak mungkin ada motivasi. Selain itu, goal juga memberikan dasar dalam pemecahan masalah dalam diri maupun dalam kelompok dan goal adalah syarat mutlak untuk penilaian dan evaluasi. Tanpa mengetahui apa tujuan dari tindakan yang dilakukan, maka tidak mungkin penilaian dapat dilakukan [9].

Individu yang memiliki komitmen pada sebuah goal, secara alami mereka akan memiliki kebutuhan untuk mencapai goal tersebut dan tidak memiliki goal yang saling berbenturan. Hal ini disebabkan karena ada hubungan linear yang positif antara kesulitan goal dan performa pengerjaan tugas. Goal merujuk pada hasil yang akan diraih kelak, dimana pembuatan goal dilakukan pada awal sebelum proses adanya ketidakcocokan. Hal ini secara tidak langsung berada di luar kondisi individu yang sekarang dan di luar hasratnya untuk meraih goal. Lebih lanjut, menurut model self-concordance yang didasari oleh teori self-determination, individu akan bertahan lebih lama dalam sebuah goal jika mereka merasa memiliki kekuasaan pribadi dalam melakukan goal dan mereka menikmati tiap proses pencapaian goal (intrinsic motivation) serta/atau menikmati tiap proses pencapaian goal ketika ada nilai-nilai yang dikandung oleh goal (dentified motivation). Secara umum, goal berhubungan dengan pengaruh yang ada pada goal yang memiliki standar untuk self-satisfaction dalam performa. Apapun bentuk goal, tinggi atau keras, akan memotivasi individu karena goal menyebabkan munculnya kebutuhan untuk meraih goal tersebut agar individu dapat merasa puas [9].

Sehubungan dengan self-efficacy (task-specific confidence, goal sering kali memediasi atau setengah memediasi efek dari variabel motivasi potensial lainnya, seperti kepribadian, umpan balik (feedback), partisipasi dalam menentukan keputusan, otonomi kerja dan dorongan keuangan [10]. Teori self-efficacy Bandura, juga memberikan perspektif lain pada motivasi yang terus-menerus [10]. Menurut beberapa studi yang sudah dilakukan pada teori ini, mereka yang yakin bahwa mereka memiliki sumber daya untuk melakukan sebuah usaha akan menunjukan 
persistensi goal dan performa yang lebih besar [11]. Moderator kunci pada goal orientation adalah umpan balik dimana individu memiliki kebutuhan untuk melihat sampai sejauh mana usaha yang mereka sedang lakukan, komitmen pada goal yang dikembangkan oleh self-efficacy dan memandang seberapa penting sebuah goal, kompleksitas tugas yang membutuhkan pengetahuan yang lebih luas dan rintangan [9].

Beberapa penelitian yang dilakukan terhadap teori goal orientation menemukan bahwa goal akan efektif apabila didapat dari berbagai sumber. Goal dapat diraih oleh individu maupun kelompok dan pengerjaan tugas tanpa goal akan menyebabkan performa goal yang rendah dan tanpa komitmen, goal tidak memiliki efek motivasional (lihat Brown, Jones \& Leigh, 2005; Locke, Shaw, Saari, \& Latham, 1981; Locke \& Latham, 1990).

\section{Dimensi-dimensi Goal orientation}

Dimensi goal orientation merupakan ciri-ciri yang dimiliki individu dengan goal orientation. Berikut ini dijelaskan sembilan dimensi dari Anderman dan Maehr (1994), Ames (1992), serta Maehr \& Midgley (1991) yang dirangkum oleh Pintrich dan Schunk [12]:

1. Definisi Kesuksesan. Individu yang memiliki goal orientation, memandang kesuksesan sebagai peningkatan, kemajuan, penguasaan suatu tugas, kreativitas, inovasi dan proses belajar.

2. Hal yang dianggap bernilai. Individu yang memiliki goal orientation, hal yang dianggap penting adalah usaha, mengerjakan tugastugas yang menantang.

3. Alasan Berusaha. Individu yang memiliki goal orientation, biasanya memiliki alasanalasan yang bersifat intrinsik dan bernilai bagi dirinya sendiri.

4. Kriteria Penilaian. Individu yang task involved memiliki kriteria penilaian yang mutlak, tidak berubah-ubah (karena berasal dari dirinya sendiri) dan memiliki bukti dari kemajuan yang dicapai.

5. Pandangan terhadap suatu kesalahan. Individu yang task involved memandang kesalahan sebagai suatu informasi baru yang didapat dan kesalahan merupakan bagian dari belajar.

6. Pola-pola Atribusi. Individu yang task involved biasanya lebih adaptif dalam menghadapi situasi tertentu, mereka menganggap kegagalan sebagai kurangnya usaha yang dilakukan, seringkali hasil yang dicapai dilihat sebagai hasil dari hasil seluruh usaha yang sudah dilakukan.

7. Afeksi. Pada individu yang task involved, kebanggaan dan kepuasaan akan dirasakan ketika individu tersebut melakukan usaha dengan sukses. Rasa bersalah akan timbul jika kurang dalam berusaha. Individu yang task involved juga memiliki sikap yang positif terhadap proses belajar dan memang secara intrinsik tertarik dengan proses belajar.

8. Kognisi. Individu yang task involved biasanya menggunakan pemikiran yang lebih mendalam ketika melakukan sesuatu, individu tersebut lebih bisa mengatur diri sendiri dengan hal-hal yang berkaitan dengan perencanaan, kesadaran dan self monitoring.

9. Tingkah laku. Individu yang task involved lebih memilih tugas yang dianggap menantang dan memiliki resiko yang cukup besar. Individu tersebut juga terbuka dengan tugas-tugas yang baru dan memiliki tingkat prestasi yang lebih tinggi.

Dimensi-dimensi goal orientation task involved tersebut merupakan dimensi yang digunakan dalam mengukur goal orientation task involved individu.

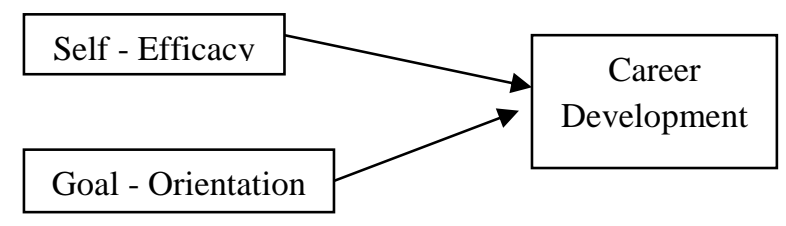

Gambar 1. Model teoritik

Secara sederhana digambarkan pada Gambar 1, bahwa self-efficacy dan goal orientation seseorang yang bersifat individual, diperkirakan akan dapat mempengaruhi career development dari para pencari kerja. Serta signifikasi korelasi selfefficacy dan goal orientation terhadap career development dari seorang pencari kerja. Selain itu diharapkan melalui penelitian ini dapat dilihat bagaimana kontribusi atau sumbangan efektif masing-masing variabel (exogen) atau kedua variaiabel secara bersama-sama terhadap career development. Dan melihat bagaimana kemampuan prediktif self-efficacy dan goal orientation terhadap career development. 


\section{METODE PENELITIAN}

Penelitian ini menggunakan metode kuantitatif dengan sampel para pencari kerja di Jakarta Selatan. Adapun variabel yang akan dibahas dalam penelitian ini terdiri dari:

1. Variabel Bebas: Self efficacy dan Goal
orientation

2. Variabel Terikat: Career Development

\section{Populasi dan Sampel Penelitian}

Jumlah populasi pada penelitian ini sebanyak 749 individu. Populasi yang Jumlah sampel yang diambil merupakan sebagian dari jumlah populasi penelitian yang berdasarkan tabel Kretjie Morgan [13], sehingga didapat sampel sebanyak 254 orang. Sampel digunakan dalam penelitian ini adalah individu yang mengirimkan surat lamaran ke outsourcing PT. Bina Talenta

\section{HASIL PENELITIAN}

Pada bab ini berisi tentang laporan penelitian, yaitu laporan pelaksanaan penelitian yang meliputi pelaksanaan uji coba yaitu validitas faktor pada alat ukur kemudian dilanjutkan dengan laporan pelaksanaan penelitian dan hasil analisis data.

\section{Hasil Analisis Instrumen \\ Uji Validitas Item}

Setelah melakukan uji coba dan mendapatkan data, maka dilakukan uji validitas item untuk masingmasing skala pengukuran. Skala career development yang terdiri dari item yang terbagi atas 20 item favorable dan 20 item unfavorable dimana item yang valid 36 yang gugur 4 item, skala self efficacy terdiri dari 42 item yang meliputi 21 item favorable dan 21 item unfavorable. Dari hasil analisis data yang dilakukan maka diperoleh bahwa item yang valid berjumlah 37 item dan yang gugur 5 item. Nilai koefisien korelasi (rit) bergerak dari 0.430 hingga 0.749. Hasil penelitian terhadap validitas item skala self efficacy dapat dilihat pada table 2.

Setelah dilakukan analisis item terhadap skala etika kerja, maka dapat diketahui dari 40 item, 36 item dinyatakan layak untuk penelitian dan 4 item dinyatakan gugur.

Tabel 2. Blue Print Skala Career Development

\begin{tabular}{|c|c|c|c|c|c|}
\hline No & Faktor & Indikator & Fav & Unfav & Jmlh \\
\hline \multirow[t]{4}{*}{1} & \multirow{4}{*}{$\begin{array}{c}\text { Tanggung } \\
\text { jawab }\end{array}$} & a. Tanggung jawab terhadap pekerjaan & 1,21 & 10,15 & 4 \\
\hline & & b. Tanggung jawab terhadap hasil pekerjaan & 11,37 & 3,22 & 4 \\
\hline & & c. Tanggung jawab atas dampak pekerjaanya & 4,6 & 12,36 & 4 \\
\hline & & terhadap kepentingan orang lain & & & \\
\hline \multirow[t]{2}{*}{2} & \multirow[t]{2}{*}{ Keadilan } & a. Tidak merugikan hak orang lain & 13,34 & 2,19 & 4 \\
\hline & & b. Tidak melakukan diskriminasi & 14,16 & 24,27 & 4 \\
\hline \multirow[t]{2}{*}{3} & \multirow[t]{2}{*}{ Otonomi } & a. Komitmen pekerjaan & 18,40 & 9,38 & 4 \\
\hline & & b. Menghargai otonomi kaum pekerja & $8 *, 39$ & $17,23^{*}$ & 2 \\
\hline \multirow[t]{3}{*}{4} & \multirow{3}{*}{$\begin{array}{c}\text { Integritas } \\
\text { Moral }\end{array}$} & a. Tidak mudah kalah & $25^{*}, 28$ & 5,20 & 3 \\
\hline & & b. Tidak mudah menyerah & 26,29 & 32,33 & 4 \\
\hline & & c. Malu & 7,35 & $30^{*}, 31$ & 3 \\
\hline & & Jumlah & 18 & 18 & 36 \\
\hline
\end{tabular}


Tabel 3. Item yang valid dan droop pada skala self efficacy

\begin{tabular}{|c|c|c|c|c|c|}
\hline \multirow[b]{2}{*}{ No } & \multirow[b]{2}{*}{ Dimensi } & \multirow[b]{2}{*}{ Indikator } & \multicolumn{2}{|c|}{ Item } & \multirow{2}{*}{$\begin{array}{l}\text { Jml Item } \\
\text { Valid }\end{array}$} \\
\hline & & & Favo & Unfavo & \\
\hline \multirow[t]{3}{*}{1.} & \multirow[t]{3}{*}{$\begin{array}{l}\text { Tingkat } \\
\text { kesulitan tugas }\end{array}$} & $\begin{array}{l}\text { a. Mampu melaksanakan tugas } \\
\text { yang sederhana }\end{array}$ & $1^{*}, 15^{*}, 29$ & $8,22,36$ & 4 \\
\hline & & $\begin{array}{l}\text { b. Mampu melaksanakan tugas } \\
\text { yang agak sulit }\end{array}$ & $2,16,30$ & $9,23,37 *$ & 5 \\
\hline & & $\begin{array}{l}\text { c. Mampu melaksanakan tugas } \\
\text { yang sangat sulit }\end{array}$ & $3,17,31$ & $10,24,38$ & 6 \\
\hline \multirow[t]{2}{*}{2.} & \multirow[t]{2}{*}{ Situasi umum } & $\begin{array}{l}\text { a. Yakin akan kemampuan pada } \\
\text { pada situasi tertentu }\end{array}$ & $4,18,32$ & $11,25,39$ & 6 \\
\hline & & $\begin{array}{l}\text { b. Yakin akan kemampuan pada } \\
\text { pada situasi yang bervariasi }\end{array}$ & $5,19,33$ & $12,26,40$ & 6 \\
\hline \multirow[t]{2}{*}{3.} & \multirow{2}{*}{$\begin{array}{l}\text { Kekuatan } \\
\text { dalam } \\
\text { melaksanakan } \\
\text { tugas }\end{array}$} & $\begin{array}{l}\text { a. Menyukai tugas-tugas yang } \\
\text { menantang }\end{array}$ & $6,20^{*}, 34$ & $13,27,41$ & 5 \\
\hline & & $\begin{array}{l}\text { b. Tidak mudah menyerah } \\
\text { menghadapi tugas }\end{array}$ & $7,21,35$ & $14^{*}, 28,42$ & 5 \\
\hline \multicolumn{3}{|c|}{ Jumlah Item Valid } & 18 & 19 & 37 \\
\hline
\end{tabular}

Keterangan: *item yang gugur

Skala goal orientation terdiri dari 60 item yang meliputi 30 item favorable dan 30 item unfavorable. Dari hasil analisis data yang dilakukan, maka diperoleh bahwa item yang valid berjumlah 51 dan item yang gugur berjumlah 9 .
Nilai koefisien korelasi (rit) bergerak dari 0.330 hingga 0.750. Berikut adalah hasil penelitian terhadap valitidas item skala goal orientation task involved:

Tabel 4. Item yang valid dan droop pada skala goal orientation

\begin{tabular}{|c|c|c|c|c|}
\hline \multirow{2}{*}{ No } & \multirow{2}{*}{ Dimensi } & \multicolumn{2}{|c|}{ Item } & \multirow{2}{*}{$\begin{array}{l}\text { Jml Item } \\
\text { Valid }\end{array}$} \\
\hline & & Favo & Unfavo & \\
\hline 1. & $\begin{array}{lll}\begin{array}{l}\text { Kesuksesan } \\
\text { peningkatan }\end{array} & \text { sebagai } & \text { suatu } \\
\end{array}$ & $1,21,41$ & $11,31,51$ & 6 \\
\hline 2. & $\begin{array}{l}\text { Usaha sebagai hal yang bernilai } \\
\text { bernilai }\end{array}$ & $22,22 *, 42$ & $12,32,52$ & 5 \\
\hline 3. & $\begin{array}{l}\text { Usaha untuk mendapatkan sesuatu } \\
\text { yang baru }\end{array}$ & $3,23,43$ & $13,33,53$ & 6 \\
\hline 4. & Kriteria penilaian yang mutlak & $4^{*}, 24,44$ & $14,24,54$ & 5 \\
\hline 5. & Kesalahan adalah bagian dari belajar & $5,25,45$ & $15,35,55$ & 6 \\
\hline 6. & $\begin{array}{l}\text { Pola-pola atribusi yang merupakan } \\
\text { bukti kemampuan }\end{array}$ & $\begin{array}{c}6,7,26^{*}, 27^{*}, \\
46^{*}, 47^{*}\end{array}$ & $\begin{array}{l}16^{*}, 17,36^{*}, \\
37,56,57\end{array}$ & 6 \\
\hline 7. & $\begin{array}{l}\text { Perasaan bersalah karena kurangnya } \\
\text { usaha }\end{array}$ & $8,28^{*}, 48$ & $18,38,58$ & 5 \\
\hline 8. & $\begin{array}{l}\text { Mempunyai perencanaan yang } \\
\text { matang }\end{array}$ & $9,29,49$ & $19,39,59$ & 6 \\
\hline 9. & $\begin{array}{l}\text { Menyukai tugas-tugas } \\
\text { menantang }\end{array}$ & $10,30,50$ & $20,40,60$ & 6 \\
\hline & Jumlah & 23 & 28 & 51 \\
\hline
\end{tabular}

Keterangan: *item yang gugur 


\section{Uji Korelasi antar Faktor}

Setelah menganalisis item-item yang valid, selanjutnya dilakukan analisis koefisien korelasi antar faktor. Uji korelasi antar faktor ini dilakukan untuk melihat apakah faktor-faktor yang ada dalam skala pengukuran yang digunakan saling berkorelasi satu sama lain atau tidak. Analisis antar faktor ini dilakukan dengan cara melihat korelasi antara faktor dengan faktor dan faktor dengan total. Setelah item-item yang valid dari setiap faktor diperoleh, maka item-item yang valid tersebut dianalsis, sedangkan item yang gugur dibuang. Secara garis besar hasil dari pengujian korelasi antar faktor dapat dilihat pada tabel 5.

Tabel 5. Uji Korelasi Antar Faktor Skala Career Development Correlations

\begin{tabular}{|c|c|c|c|c|c|c|}
\hline & & F1 & F2 & F3 & F4 & TS \\
\hline \multirow[t]{3}{*}{ F1 } & $\begin{array}{l}\text { Pearson } \\
\text { Correlation }\end{array}$ & 1 &, $568(* *)$ &, $828(* *)$ & ,901(**) & ,949(**) \\
\hline & Sig. (2-tailed) & . & ,001, & 000, & ,000 & ,000 \\
\hline & $\mathrm{N}$ & 30 & 30 & 30 & 30 & 30 \\
\hline \multirow[t]{3}{*}{$\mathrm{F} 2$} & $\begin{array}{l}\text { Pearson } \\
\text { Correlation }\end{array}$ & ,568(**) & 1 &, $572(* *)$ & ,658(**) &, $747(* *)$ \\
\hline & Sig. (2-tailed) & ,001 & . & ,001 & ,000 & , 000 \\
\hline & $\mathrm{N}$ & 30 & 30 & 30 & 30 & 30 \\
\hline \multirow[t]{3}{*}{ F3 } & $\begin{array}{l}\text { Pearson } \\
\text { Correlation }\end{array}$ & ,828(**) &, $572(* *)$ & 1 & ,852(**) & ,898(**) \\
\hline & Sig. (2-tailed) & ,000 & ,001 & ${ }^{\circ}$ & ,000 & ,000 \\
\hline & $\mathrm{N}$ & 30 & 30 & 30 & 30 & 30 \\
\hline \multirow[t]{3}{*}{ F4 } & $\begin{array}{l}\text { Pearson } \\
\text { Correlation }\end{array}$ & ,901(**) &, $658(* *)$ & ,852(**) & 1 & ,966(**) \\
\hline & Sig. (2-tailed) & ,000 & ,000 & ,000 & & , 000 \\
\hline & $\mathrm{N}$ & 30 & 30 & 30 & 30 & 30 \\
\hline \multirow[t]{3}{*}{ TS } & $\begin{array}{l}\text { Pearson } \\
\text { Correlation }\end{array}$ & ,949(**) &, $747(* *)$ & ,898(**) & ,966(**) & 1 \\
\hline & Sig. (2-tailed) & ,000 & ,000 & , 000 & ,000 & \\
\hline & $\mathrm{N}$ & 30 & 30 & 30 & 30 & 30 \\
\hline
\end{tabular}

Tabel 6. Korelasi antar faktor skala self efficacy

\begin{tabular}{ccccc}
\hline & F1 & F2 & $\mathbf{F 3}$ & $\mathbf{T}$ \\
\hline $\mathbf{F 1}$ & 1,000 & $0,645^{* *}$ & $0,634^{* *}$ & $0,891^{* *}$ \\
\hline $\mathbf{F 2}$ & $0,645^{* *}$ & 1,000 & $0,634^{* *}$ & $0,870^{* *}$ \\
& & & & \\
\hline $\mathbf{F 3}$ & $0,634^{* *}$ & $0,634^{* *}$ & 1,000 & $0,850^{* *}$ \\
& & & & \\
\hline $\mathbf{T}$ & $0,891^{* *}$ & $0,870^{* *}$ & $0,850^{* *}$ & 1,000
\end{tabular}


Berdasarkan tabel 6 dapat dijelaskan bahwa masing-masing faktor berkorelasi secara signifikan dengan totalnya. Begitu pula masing-masing faktor saling berkorelasi dengan nilai korelasi mendekati satu.

Tabel 7. Korelasi antar faktor skala goal orientation

\begin{tabular}{lllllllllll}
\hline & $\mathbf{F 1}$ & $\mathbf{F 2}$ & $\mathbf{F 3}$ & $\mathbf{F 4}$ & $\mathbf{F 5}$ & $\mathbf{F 6}$ & $\mathbf{F 7}$ & $\mathbf{F 8}$ & \multicolumn{1}{|c}{ 99 } & TF \\
\hline F1 & 1,000 & 0,231 & $0,444^{* *}$ & 0,140 & $0,538^{* *}$ & $0,315^{*}$ & 0,282 & $0,495^{* *}$ & $0,372^{*}$ & $0,680^{* *}$ \\
\hline F2 & 0,231 & 1,000 & 0,164 & 0,057 & 0,065 & 0,255 & $-0,093$ & 0,281 & 0,081 & $0,332^{*}$ \\
\hline F3 & $0,444^{* *}$ & 0,164 & 1,000 & 0,223 & 0,168 & $0,360^{*}$ & $0,337^{*}$ & $0,613^{* *}$ & $0,472^{* *}$ & $3,700^{* *}$ \\
\hline F4 & 0,140 & 0,057 & 0,223 & 1,000 & 0,091 & 0,083 & 0,212 & $0,517^{* *}$ & $0,442^{* *}$ & $0,504^{* *}$ \\
\hline F5 & $0,538^{* *}$ & 0,065 & 0,168 & 0,091 & 1,000 & 0,264 & $-0,005$ & 0,117 & 0,175 & $0,422^{* *}$ \\
\hline F6 & $0,315^{*}$ & 0,255 & $0,360^{*}$ & 0,083 & 0,264 & 1,000 & $0,378^{*}$ & $0,366^{*}$ & $0,496^{* *}$ & $0,659^{* *}$ \\
\hline F7 & 0,282 & $-0,093$ & $0,337^{*}$ & 0,212 & $-0,005$ & $0,378^{*}$ & 1,000 & $0,356^{*}$ & $0,517^{* *}$ & $0,574^{* *}$ \\
\hline F8 & $0,495^{* *}$ & 0,281 & $0,613^{* *}$ & $0,517^{* *}$ & 0,117 & $0,366^{*}$ & $0,356^{*}$ & 1,000 & $0,566^{* *}$ & $0,797^{* *}$ \\
\hline F9 & $0,372^{*}$ & 0,081 & $0,472^{* *}$ & $0,442^{* *}$ & 0,175 & $0,496^{* *}$ & $0,517^{* *}$ & $0,566^{* *}$ & 1,000 & $0,776^{* *}$ \\
\hline TF & $0,680^{* *}$ & $0,332^{*}$ & $0,700^{* *}$ & $0,504^{* *}$ & $0,422^{* *}$ & $0,659^{* *}$ & $0,574^{* *}$ & $0,797^{* *}$ & $0,776^{* *}$ & 1,000 \\
\hline
\end{tabular}

Berdasarkan tabel 7 dapat dijelaskan bahwa masing-masing faktor berkorelasi secara signifikan dengan totalnya. Korelasi terbesar diperoleh dari korelasi antara faktor tiga dan faktor delapan yaitu sebesar 0,613. Dan yang terkecil adalah korelasi antara faktor satu dengan faktor enam yaitu sebesar 0,315 .

\section{Uji Reliabilitas}

Setelah memperoleh item-item yang valid, maka peneliti mencari reliabilitas skala pengukuran. Berdasarkan hasil analisis alat ukur dengan menggunakan program SPSS 11,5 for windows, diperoleh koefisien relabilitas untuk skala self efficacy adalah sebesar 0.9048. Menurut kaidah Guilford \& Frucher, koefisien alpha sebesar 0.9048 menunjukkan bahwa skala self efficacy sangat reliable., sehingga skala self efficacy ini memungkinkan untuk dilanjutkan pada penelitian yang sesungguhnya. Pada skala goal orientation task involved didapat koefisien reliabilitas sebesar 0.8402 dan menunjukkan bahwa skala goal orientation task involved reliable, sehingga memungkinkan untuk dilanjutkan pada penelitian yang sesungguhnya.

\section{Hasil Analisis Data}

Analisis data penelitian dilakukan untuk menguji hipotesis yang telah diajukan. Dalam penelitian ini, dilakukan tiga pengujian hipotesis yaitu satu hipotesis mayor dan dua hipotesis minor. Hipotesis pertama dalam penelitian ini adalah hubungan antara self efficacy dan goal orientation dengan career development individu. Sedangkan hipotesis kedua adalah hubungan self efficacy dengan career deveoplment individu dan hipotesis ketiga adalah hubungan goal orientation dengan career development individu.

Berdasarkan komputasi analis korelasi ganda dengan bantuan program SPSS 11,5 for windows, diperoleh nilai $\mathrm{R}=0.650 ; \mathrm{F}=91.998$ dan $\mathrm{p}=0.000$, $\mathrm{p}<0.05$. Hal ini berarti bahwa $\mathrm{H}_{0}$ yang menyatakan tidak ada hubungan yang positif antara self efficacy dan goal orientation dengan career development individu ditolak dan Ha yang menyatakan bahwa ada hubungan yang positif antara self efficacy dan goal orientation dengan career development individu diterima.

Hasil analisis korelasi parsial diperoleh nilai koefisien korelasi (rxy) antara self efficacy dengan career development sebesar $\mathrm{rxy}=0.2678$ dan $\mathrm{p}=$ $0.000, \mathrm{p}<0.05$. ini berarti $\mathrm{H}_{0}$ yang menyatakan bahwa tidak ada hubungan yang positif antara self efficacy dengan career development individu ditolak dan $\mathrm{Ha}$ yang menyatakan bahwa ada hubungan yang positif antara self efficacy dengan career development individu diterima. Nilai koefisien korelasi (rxy) antara goal orientation dengan career development sebesar $\mathrm{rxy}=0.5930$ dan $\mathrm{p}=0.000, \mathrm{p}<0.05$. ini berarti $\mathrm{H}_{0}$ yang menyatakan bahwa tidak ada hubungan yang positif antara goal orientation dengan career development individu ditolak dan $\mathrm{Ha}$ yang menyatakan bahwa ada hubungan yang positif antara goal orientation dengan career development individu diterima. 
Dari hasil analisis regresi ganda Rsquare diperoleh nilai sebesar $R^{2}=0.423$. Hal ini berarti $42,3 \%$ career development dapat dijelaskan oleh variable self effcacy dan goal orientation. Nilai Rsquare change sebesar $\mathrm{R}^{2} \mathrm{c}=0.045$ dan 0.378 . Hal ini berarti kontribusi self efficacy terhadap career development sebesar $4,5 \%$ dan kontribusi goal orientation terhadap career development sebesar $37.8 \%$.

Dengan demikian kesimpulan dari hasil analis data tersebut adalah:

1. Ada hubungan yang positif dan signifikan antara self efficacy dan goal orientation dengan career development individu pencari kerja di PT Bina Talenta.

2. Ada hubungan yang positif dan signifikan antara self efficacy dan career development individu pencari kerja di PT. Bina Talenta

3. Ada hubungan yang positif dan signifikan antara goal orientation dengan career development individu pencari kerja di PT. Bina Talenta

\section{PENUTUP}

\section{Pembahasan}

Berdasarkan hasil uji statistik dengan menggunakan program SPSS versi 11,5 for windows diperoleh korelasi antara ketiga variabel dan korelasi masing-masing variabel bebas dan variabel terikat. Dari hasil analisis data antara ketiga variabel, diperoleh koefisien korelasi sebesar $\mathrm{R}=0.650 ; \mathrm{F}=91.998$ dengan $\mathrm{p}=0.000$, $\mathrm{p}<0.05$. Hal ini berarti $\mathrm{H}_{0}$ yang menyatakan tidak ada hubungan yang positif antara self efficacy dan goal orientation dengan career development individu ditolak dan Ha yang menyatakan bahwa ada hubungan yang positif antara self efficacy dan goal orientation dengan career development individu diterima. Dengan demikian ada keterkaitan yang signifikan antara self efficacy dan goal orientation dengan career development individu pencari kerja di PT. Bina Talenta dan arah hubungannya positif. Sehingga dapat dikatakan bahwa hubungan korelasinya berbanding lurus, yaitu semakin tinggi nilai self efficacy dan goal orientation maka semakin tinggi pula career developmentnya.

Hasil koefisien korelasi pada uji hipotesis kedua, diperoleh koefisien korelasi sebesar $\mathrm{rxy}=0.2678$ dan $\mathrm{p}=0.000, \mathrm{p}<0.05$. Hal ini berarti $\mathrm{H}_{0}$ yang menyatakan bahwa tidak ada hubungan yang positif antara self efficacy dengan career development individu ditolak dan $\mathrm{Ha}$ yang menyatakan bahwa ada hubungan yang positif antara self efficacy dengan career development individu diterima. Dengan demikian ada keterkaitan yang signifikan dan berkorelasi secara positif antara self efficacy dengan career development individu pencari kerja Pt. Bina Talenta. Sehingga dapat dikatakan semakin tinggi nilai self efficacynya maka semakin tinggi pula career developmentnya.

Hasil koefisien korelasi pada uji hipotesis ketiga, diperoleh koefisien korelasi sebesar $\mathrm{rxy}=0.5930$ dan $\mathrm{p}=0.000, \mathrm{p}<0.05$. ini berarti $\mathrm{H}_{0}$ yang menyatakan bahwa tidak ada hubungan yang positif antara goal orientation dengan career development individu ditolak dan $\mathrm{Ha}$ yang menyatakan bahwa ada hubungan yang positif antara goal orientation dengan career development individu diterima. Dengan demikian ada keterkaitan yang signifikan dan berkorelasi secara positif antara goal orientation dengan career development individu pencari kerja PT. Bina Talenta. Sehingga dapat dikatakan semakin tinggi nilai goal orientation maka semakin tinggi pula career developmentnya.

Dalam penelitian ini juga, dilakukan uji analisis regresi ganda. Dari hasil analisis regresi ganda Rsquare diperoleh nilai sebesar $\mathrm{R}^{2}=0.423$. Hal ini berarti $42,3 \%$ nilai career development individu pencari kerja PT. Bian Talenta dapat dijelaskan oleh variable self effcacy dan goal orientation. Self efficacy mempunyai pengaruh terhadap career development individu sebesar $4,5 \%$ dan goal orientation sebesar $37,8 \%$. Sedangkan sisanya $62,2 \%$ dijelaskan oleh variabel-variabel yang lain, misalnya, intelegensi, bakat, minat, peranan keluarga dan masyarakat (Muhibbin Syah, 2003:132).

Katagorisasi dilakukan berdasarkan signifikansi perbedaan, yaitu dengan menguji signifikansi perbedaan antara mean skor empiris atau mean sampel (M) dan mean skor teoritis atau mean skor populasi $(\mu)$. Cara ini bertujuan untuk menempatkan individu kedalam jenjang-jenjang rendah, sedang, dan tinggi namun tidak mengasumsikan distribusi populasi yang normal (Saifuddin Azwar, 2003: 114). Berdasarkan kategorisasi ordinal untuk self efficacy, diperoleh skor kategori rendah <110, kategori sedang 110113, dan kategori tinggi >113, sedangkan mean skor empiris 132, berarti skor rata-rata kelompok 
berada pada kategori tinggi. Adapun individu yang termasuk kedalam kategori rendah sebesar 4\%, individu termasuk kedalam kategori sedang sebesar 4\%, dan individu yang termasuk kedalam kategori tinggi sebesar $92 \%$. Sedangkan kategorisasi ordinal untuk goal orientation task involved, diperoleh skor kategori rendah $<151$, kategori sedang 151-155, dan kategori tinggi $>155$, sedangkan mean skor empiris 183. Berarti bahwa skor rata-rata kelompok berada pada kategori tinggi. Adapun individu yang termasuk kedalam kategori rendah sebesar $0 \%$, individu yang termasuk kedalam kategori sedang sebesar $2 \%$, dan individu yang termasuk kedalam kategori tinggi $98 \%$.

Dari hasil kategorisasi diatas, dapat dilihat bahwa mean skor kelompok pada ketiga variabel berada pada kategorisasi tinggi. Hal ini berarti, individu dengan self efficacy dan goal orientation yang tinggi cenderung memperlihatkan tingkat career development yang tinggi pula.

\section{Kesimpulan}

Berdasarkan hasil analisis data penelitian dan pembahasan yang telah diuraikan diatas, maka dapat disimpulkan bahwa:

1. Terdapat hubungan yang positif dan signifikan antara self efficacy dan goal orientation dengan career development individu pencari kerja PT. Bina Talenta.

2. Terdapat hubungan yang positif dan signifikan antara self efficacy dan career development individu pencari kerja di PT. Bina Talenta.

3. Terdapat hubungan yang positif dan signifikan antara goal orientation dengan career development individu pencari kerja di PT. Bina Talenta

\section{Saran}

Berdasarkan hasil dan kesimpulan yang telah diuraikan diatas, maka peneliti mengajukan beberapa saran sebagai berikut:

1. Saran teoritis

a. Menunjuk pada hasil penelitian, bahwa kontribusi self efficacy dan goal orientation terhadap career development individu sebesar $42,3 \%$, yaitu $4 \%$ kontribusi self efficacy dan $37,8 \%$ goal orientation dan sisanya dijelaskan oleh faktor-faktor lain, misalnya intelegensi, minat, dan bakat, peneliti berharap untuk selanjutnya adanya penelitian lain yang meneliti faktor-faktor lainnya terhadap career development. $b$. Berdasarkan hasil penelitian yang menyatakan bahwa ada hubungan goal orientation dengan career development, disarankan ada penelitian lain yang mengangkat mengenai jenis goal orientation yang lainnya, yaitu ego involved terhadap career development.

2. Saran praktis

Hasil kategorisasi, memperlihatkan bahwa tingkat self efficacy dan goal orientation individu berada pada tingkat tinggi, untuk itu diharapkan:

a. Kepada para dosen atau pengajar, untuk dapat menciptakan suasana kelas yang dapat mendorong individu untuk lebih menjelaskan pengembangan karir setelah lulus dan memberikan pengarahan mengenai pentingnya usaha untuk mendapat hasil yang maksimal.

b. Kepada orangtua, diharapkan dapat memberikan bimbingan dan mendorong anak untuk menumbuhkan keyakinan tentang kemampuan dirinya mengerjakan tugas dan mencapai tujuan yang diinginkan guna mendapatkan hasil yang maksimal.

c. Kepada mahasiswa atau individu, agar mendapatkan prestasi yang baik diharapkan tetap mempertahankan keyakinan diri akan kemampuan yang dimiliki dengan tidak mudah putus asa dan lebih memfokuskan diri untuk meningkatkan kemampuan dengan berorientasi pada tujuan, misalkan dengan lebih fokus dan semangat dalam berusaha

\section{DAFTAR PUSTAKA}

[1] A.J. Tjahjoanggoro, Hubungan antara jangkar karir dan hambatan pribadi dengan kesuksesan karir pada para staf eksekutif perbankan di kotamadya Surabaya, Jakarta: Universitas Indonesia, 1994.

[2] E.H. Schein, Organizational culture and leadership. San Francisco : Jossey-Bass Publishers, 1991.

[3] G. Dessler, Human Resource Management. Prentice Hall. 1997.

[4] V. Rivai, Manajemen Sumber Daya Manusia untuk Perusahaan: dari Teori Ke Praktik, Edisi Pertama, Jakarta: PT. Raja Grafindo Persada, 2006.

[5] H. Simamora, Manajemen Sumber Daya Manusia, Yogyakarta : STIE YKPN, 2001.

[6] R.W. Mondy, Manajemen Sumber Daya Manusia (terj.), Jilid I, Jakarta: Erlangga, 2008. 
[7] C. Wade, C. Tavris, Invitation to Psychology (4th Edition) (MyPsychLab Series), Pearson, 2007.

[8] A. Bandura, "The explanatory and predictive scope of self-efficacy theory", Journal of Clinical and Social Psychology, 4, 1986.

[9] G.P. Latham, Work Motivation, London : Sage Publication, 2007.

[10] A. Bandura, Self-efficacy: The Exercise of Control, New York: Freeman, 1997.
[11] K.M. Sheldon, M.L. Houser and T. Kasser, "Does autonomy increase with age? Comparing the motivation and well-being of college students and their parents", Journal of Research in Personality, 40, p. 168-178, 2006.

[12] P. Pintrich, D. Schunk, Motivation in Education: Theory, Research \& Applications, Ch. 3. Englewood Cliffs, NJ: Prentice-Hall, 1996.

[13] Sugiyono, Statistik Nonparametrik untuk Penelitian, Bandung: Alfabeta, 2001. 